\title{
PARATROOPERS IN THE INTELLIGENCE CONFRONTATIONS DURING THE SECOND WORLD WAR
}

\author{
Mircea TĂNASE \\ Ministry of National Defense, Bucharest, Romania \\ mirceatanase2003@yahoo.com
}

\begin{abstract}
Characterised by the capability to rapidly penetrate the enemy disposition, at long distance, by air, using transport aircraft, by parachuting or landing, as well as by own combat capacity, airborne troops could successfully execute a wide range of specific missions, either independently or in cooperation with other units or large units in the land, air or naval forces, to meet the operational and strategic goals. Mention should be made that almost all belligerents in the Second World War successfully employed groups of well-trained fighters, parachuted behind the enemy disposition, to execute intelligence missions: information collection, "commando"-type diversionary actions, as well as supply of weapons for local partisans and resistance formations.
\end{abstract}

\section{KEYWORDS: airborne troops, paratroopers, intelligence, commando, partisans}

\section{Introduction}

In the major airborne operations of the Second World War intelligence has played a decisive role in gaining success or compromising this, if we talk only about the Allied landings in Normandy (Operation Overlord in June 1944), when the intelligence built a spectacular surprise that supported success of the action and airborne operation in Holland (operation Market Garden in September 1944), when the lack or ignoring the information made as a renowned historian concluded, "to be written an odyssey and a tragedy to be played "[1].

Along with these airborne operations, fighter paratroopers were used in the broad spectrum of the intelligence community, we could define the active side, with direct actions specific for that period, when technical means had not reached the possibilities we know - or just we suppose today, research assignments and diversion type "commando" attack and neutralize enemy vital centers of major commands, aerodrome and communication lines etc., as well as arming local partisan elements.

For the Soviets, at least, we can say that diversion operations have been more successful than actual airborne operations, representing an outstanding adjuvant in the successful guerrilla war in 1943 and 1944, but these will be the subject for other article.

\section{Airborne and special German actions} Germany created the first battalion of paratroopers from January 29, 1936, at the initiative of Colonel (later General) Kurt Student, supported by Herman Göring, head of the Luftwaffe, prestigious aviator of the World War I, and after 1920 representative firms parachutes "Heinecke" and "Thörnbland"- who convinced Hitler of the need to create this elite corps of the German army. On April 1, 1938, the battalion of paratroopers became 1st Paratroopers Regiment, part of the 7th Airborne Division/7 Fliegerdivision, founded in the summer of that year, whose commanding 
officer was General Student. In the same year, 1938, there were established the feared "Brandenburg" detachments, comprising excellent trained volunteers, fluent in several languages, trained for missions by parachute into the enemy lines. On September 1, 1939, a group of 80 soldiers from the elite corps, led by Lieutenant Gräbert acted in triage Katowice in Poland, opening the series of hostilities of the Second World War [2], where the German Airborne troops will be both winning and losing during all this war.For the occupation of Denmark and Norway in April 1940, nearly 500 transport aicraft, three-engined Junkers Ju-52, heavy Junkers $J u-90$ and Focke-Wulf FW-200 transported by air paratroopers and airborne units. Liddell Hart stated that "it was also used a battalion of paratroopers - to capture the airports in Oslo and Stavanger. It was for the first time in the war when airborne troops were used, their contribution proving to be extremely important [...]. The mission to capture Oslo was assigned to paratroopers, who landed on Fornebu airport; in the evening, this symbolic force marched through the city, in what was supposed to intimidate the Norwegians" [3]. For Operation Gelb - the German Offensive against Netherlands, Belgium and France, a "Panzerdivision" should have been attacked the central part of the Netherlands, and another division, the southern part of the country and then to move forward to Belgium. The airborne corps, under the command of Lieutenant-General Kurt Student, had to conquer the vital points to ensure the advance of the armored troops and to interconnect with them. "Airborne troops get in action. They are launched on Vaalhaven airfield, near Rotterdam, on the Hague and on Dordrecht island, near the big port of Moerdik. In the Netherlands, the main airfields and communication nodes are intercepted" [4].

12 Heinkel-59 seaplanes landed paratroopers from the detachment commanded by Lieutenant Schrader, who went up to the double bridge over the Meuse, without leaving any reaction time for the Dutch. Meanwhile, a group of paratroopers, who landed on a stadium, on the southern side of the bridge, supported their colleagues that were parachuted from the seaplanes, and during all this time they commandeered several trams. Paratroopers of Captain KarlLothar Schultz were dropped east of the Waalhaven airfield, drawing into battle the Dutch forces that were trying to defend it, in order for a battalion from the 16th Airborne Infantry Regiment to land without any difficulties and in a short period of time conquered the airfield. In the Hague, German paratroopers in Dutch uniforms managed to confuse the local people, being confused with the Dutch army. At 15th May 1940, 9.30 a.m., "The Netherlands surrenders. General Henri Winkelman orders the cessation of hostilities. The Hague surrenders without fighting.[...]In Belgium, nazi paratroopers conquer the bridges in the area of MaastrichtVeldmezelt and Vroenhoven on the Albert Canal. Paratroopers of Lieutenant Colonel Mikosch reach the front of the fortress Eben-Emael" [5].

For the assault of this fortress, ranked as the most modern in the world, and designed to protect the three bridges, nine of Lieutenant Witzig's gliders landed on her superstructure, German pioneers managing to neutralize artillery sites and observation posts. Almost 1,000 Belgian soldiers were taken prisoner and their surprise was greater when they saw the small number of German paratroopers who had occupied the fort. On May 27, 1940 the Belgian King Leopold surrendered. At June 21, 1940, France, who was also defeated, was forced to sign an armistice [6].

In anticipation of the operation Mercury the conquest of Crete in May 1941 Germans launched several airborne formations in the islands of Limnos, Thasos and Samothrace, in northeast Aegean Sea, between April 24 to 29, 1941, and captured on 26 April 1941 the metallic bridge over the Corinth canal in to cut the withdrawal means through Peloponnesus for the British 
troops and the Commonwealth ones. The element of surprise was represented by sappers-paratroopers, carried by three gliders DFS-230, which landed precisely and smoothly at both ends of the bridge, neutralizing guard and devices to destroy it before the defenders to react, 200 aircraft Junkers -52 have dropped by a battalion of paratroopers on each side of the channel. The British managed to destroy anti-aircraft Bofors gun using the bridge, which hit a bunch of explosives disconnected.

On September 12, 1943, a company of paratroopers under the command of Otto Skorzeny, landed gliders near the hotel "Campo Imperatore" in Gran Sasso, Abruzzi Mountains, at over 2,200 m altitude, where Benitto Mussolini was arrested by their compatriots and without encountering any resistance from Italian guard, "Il Duce" was on board a glider and transported to the German base "practice di Mare" near Rome, and from there to Vienna [7]. Battalion 500th SS, created in the same period of Skorzeny, the SS officers and volunteers, as well as rehabilitation of prisoners eager, was tasked with other special missions. Trying to capture Yugoslav leader Josip Broz Tito, in June 1944, it resulted however in failure after three days of fighting with paratroopers Germans he managed to escape through a secret exit of the cave that is his point of order. The same SS battalion in October 1944, imposed a new pro-german government in Budapest, baffling Admiral Horthy's intention to conclude a separate peace with the Soviets.

During the riposte in Ardennes, in December 1944, through which the Germans hoped to conquer again the strategic advantage in Western Europe which can be a model in terms of creating diversion by misinformation to the effect exceeded the expectations of its initiators [8]. Otto Skorzeny, now commander of the 150th Brigade Commando, sent his men to the rear allied team uniforms American to occupy the bridges of the Meuse and to cause confusion among allied troops. In a first step, a commando company whose people speak English, and entered with 40 jeeps into the alloy when the front was pierced. Their mission was to disrupt phone lines, to redirect traffic signs and suggestions to the roads are blocked. Confusion among Americans was able to lead them to take the most severe measures clamping teams walked freely to the rear, with the first resulting in a huge traffic jam for search saboteurs. Panic created by the assumption that many of these gangs operate freely and rumor that tasked assassinate Eisenhower and other senior military commanders allies have imposed their taking precautions exaggerated and embarrassing, they have hampered considerably freedom of action over almost ten days [9].

\section{Allied paratroopers in airborne operations and special missions.}

In 1940 England created the first battalion of paratroopers and on September 1, 1941 was established 1st Aerotransport Brigade, which soon will increase herds and become First Airborne Division [10]. In 1942 it was created the 6th Airborne Division and the two structures together with bands like the US, particularly Divisions 82nd and 101st Airborne, created in mid-August 1942, were covered with glory in major airborne operations allied in the second part of the Second World War. Simultaneously, small groups of paratroopers behind enemy launched, would it create its unpleasantness, some of the most spectacular consequences.

In France, on February 27, 1942, he was executed a raid to destroy airborne (removal) radar station at Bruneval near Le Havre, which was part of the coastal network installed by the Germans to rein in aviation English. Operation entrusted Major Frost and Company "C" of the 2nd Battalion Parachute English, recently established, was the launch of three groups of paratroopers, after previously had been executed an airstrike. The first group neutralized German defenses at Bruneval 
second blocked a nearby German position, where there were over 100 people, and the third took radar station itself and dismantled it. Upon successful completion of the mission, 119 British paratroopers were boarded ships were waiting for them with the most important parts of the radar station. Their losses amounted to three dead, seven wounded and six missing [11].

In Norway, the plant in Vemork, located a few kilometers from Rjukan, in a mountainous region, the Germans were producing heavy water needed for making atomic bomb. For destruction of the plant Operation Freshman - on November 19, 1942, a detachment English be among paratroopers Companies 9 and 267 troops genius, under Lieutenant Allen and Matthew, was embarked in two gliders Horsa, towed aircraft Halifax at based on Skitten, Scotland. One of them was broken glider towing cable and was struck by mountains, its survivors being trapped and executed. No other crew had a better fate and thus the operation failed. On February 27, 1943, a detachment of Norwegian research has managed to destroy the plant in Vemork [12].

In many of their actions in Europe, and especially in France, paratroopers allies have supported cooperation with the resistance elements, especially the French Resistance who were asked to mark areas where he would parachute research groups and later if permitted land, jeeps armament necessary. In France they were created over 43 bases action and small groups consisting usually of four people, which included often and French or Belgian trained in England for such missions were launched in German bullying communication lines.

In June 1940, when the British founded the first school of paratroopers, a first subunit Commando 2 - was transformed into a body dedicated to particular tasks by parachute under the name Battalion 11 SAS (Special Air Service). On February 10, 1941, a detachment under the command of Major Pritchard, 7 officers and 31 paratroopers destroyed aqueduct from Tragino in the mountains Abruzzi in southern Italy, which supplied drinking water ports serving the foundation German-Italian North Africa. Unfortunately detachment could not be recovered with a submarine the next morning and was fully captured.

In June 1940, Major David Stirling, from the Scottish Guard, established a Special Forces unit called Detachment L/SAS Brigade, to refuel existing rumors about the presence of a parachute brigade in North Africa. The unit was to be transported to the target group Deep Desert Journey/Long Range Desert Group/LRDG and would perform strategic missions deep underground to destroy German airfields and installations in the Middle East.

After the first operation failed - Crusader, attacking an airfield German assaulting airborne - due to loss/capture of 42 of the 61 officers and soldiers who landed in a wrong area during one of the biggest storms of the past 30 years groups commando made up of four people, continued to be launched at 10 to 12 miles of enemy airfields, after executing reconnaissance over 100 enemy planes were destroyed on the ground with fire bombs, plastic explosives delayed, inserted into the reservoir. Meanwhile, terrestrial nocturnal raids into enemy ports and airports, where planting bombs and incendiary devices have been very successful (Lewes bomb, the first portable explosive and incendiary invented by Jock Lewes). At their turn American Jeeps, which have mounted machine guns, proved very suitable harsh desert conditions. In August 1942 these groups were the 1st Regiment SAS commando, composed of four British squadrons, one French and one Greek and a special boat squadron.

Diversionary raid on the port of Benghazi (Operation Bigamy) led directly by Stirling, was not as successful as expected because of the presence of English in the early morning. Following actions on Jalo oasis (Operation Nicety) and aerodrome BARC (Operation Caravan), where British commandos destroyed 16 aircraft and 
damaged many others and the main barracks aerodrome. It is supposed that, in reality, the operations had other codenames, which are still kept secret.

In Tunisia, after the battle of El Alamein, along the $900 \mathrm{~km}$ of coastal road linking Marbl Arsh with Tripoli, SAS groups executed several night raids on columns German, forcing them to move on and British aviation expose bombing.

Stirling himself personally led most of these actions like hit and run, which gave him notoriety, but he was captured by the Germans at the beginning of 1943 by a special German anti-SAS unit. He spent the rest of the war as a prisoner, escaping many times until he was moved in Colditz Castle. Under his command, in the 15 months of activity before being captured, SAS managed to destroy more than 250 aircraft on the ground, dozens of deposits, hundreds of vehicles, railways and telecommunications. Field marshal Montgomery described the Stirling him as "mad, quite mad", but admitted that it took people like him during the war.

1st SAS Regiment continued commando action in Sicily and southern Italy, before being brought to England, and in April 1943 was reorganized as Squadron Special raids and Special Boat Squadron [13]. The second unit has operated in the Aegean and the Balkans by the end of the war, was disbanded in 1945.

The second SAS regiment was created in Algeria in May 1943, under the command of Lieutenant Colonel William (Bill) Stirling's brother David, and will play an important role in Europe's future actions.Operation Husky - Allied invasion of Sicily in July 1943 - was supported by Special Raids Squadron /1st SAS Regiment and 2nd SAS Regiment: operation Narcissus (a raid carried out 40 fighters on a lighthouse on the south-eastern Sicily) and operation Chestnut (two teams of 10 people in northern parachuted in the night of July 12, 1943, with a mission to disrupt enemy communications path).
In Italy, SAS fighters were engaged in the operation Begonia, airborne component in the Jonquil operation (2 to 6 October 1943), when 61 people were parachuted from Ancona and Pescara, with the mission to recover the prisoners of war allies. Also on October 27, 1943, two SAS Regiment executed an airborne raid - operation Candytuft - on the east coast of Italy between Ancona and Pescara, with a mission to destroy the railway bridges.

SAS, since the beginning tried to supply and train the French Resistance units, which sometimes caused them considerable losses due to the hard strikes by the German occupiers, but this support it was best seen during landings in Normandy - Operation Overlord in June 1944 - when elements of the SAS brigade were launched behind German lines in support of the French resistance. Thus, 144 people from 1st SAS Regiment took part in the operation Houndsworth between June and September 1944, in areas Lyon, Chalon-sur-Saône, Dijon, Le Creusot and Paris, while 56 people participated in the operation Bulbasket, near Poitiers. Perhaps betrayed, these were surrounded by an impressive German force and 32 of them were captured and executed.

In mid-June, 150 people in the French SAS Regiments and 3,000 members of the French Resistance took part in the operation Dingson. During the same period, SAS French fighters were engaged in the operations Cooney, Samwest and Lost.

In August 1944, during Operation Loyton, 91 people from 1st Regiment SAS were launched in the Vosges, but the bad weather prevented their supply by air, and surrounded by Germans, 31 of them were captured and executed. Instead, the fighters of the 2nd Regiment SAS were supplied from the air and led successful actions in cooperation with the French resistance in the forests of Rennes and the Loire, in the woods of Darney to Belfort

Towards the end of 1944, elements of the 2nd Regiment SAS were parachuted in Italy in support of resistance Italian in Operation 
Tombola, acting alongside guerrillas Italian and Russian prisoners of war escaped behind German lines to destroy airfields, attack convoys and the trains. In early 1945 , a detachment of two SAS Regiment, under the command of Major Roy Farran, raided the German Corps Command located in Valley Pro, finished killing the chief of staff of the body.

In March 1945 the SAS Brigade command was appointed Brigadier Mike Calvert, former commander of Chindits/Indian Special Forces.

At the end of the Second World War, the balance of SAS was 7733 enemies killed or wounded and more than 23,000 prisoners.
In turn, SAS lost 330 people. In September 1945, Brigade SAS was disbanded by passing the 5th SAS Belgian Regiment to the new Belgian army starting from 1 October. Also, the 3rd and 4th French Regiments to were assigned to the French Army, and at October 8, 1945, the 1st and 2nd British SAS regiments were disbanded.

\section{Conclusions}

Allies and Axis countries have successfully used groups of well-trained fighters, start by parachute behind the enemy lines, throughout the war, and after, in what would be called the Cold War.

\section{References}

[1] Popişteanu, Cristian,Prefaţă la Cornelius Ryan, Un pod prea îndepărtat, Bucureşti, Editura Politică, 1977, p.9.

[2] Soare, Vasile, Forţele speciale-comadouri aeropurtate în acţiune, Bucureşti, Editura Ziua, 2002, pp.69-75.

[3] Hart, Liddel, Istoria celui de-al doilea război mondial, București, Editura Orizonturi, Editura Lider, vol.1, f.a., pp. 87-89.

[4] Loghin, Leonida, Al doilea război mondial (cronologie), Bucureşti, Editura Politică, 1984, p.33.

[5] Loghin, Leonida, Al doilea război mondial (cronologie), Bucureşti, Editura Politică, 1984, p. 35.

[6] Loghin, Leonida, Al doilea război mondial (cronologie), Bucureşti, Editura Politică, 1984, Op. cit., pp.39, 47.

[7] Loghin, Leonida, Al doilea război mondial (cronologie), Bucureşti, Editura Politică, 1984, p.300.

[8] Loghin, Leonida, Loghin, Leonida, Al doilea război mondial (cronologie), București, Editura Politică, 1984, p. 419.

[9] Hart, Liddell, Istoria celui de-al doilea război mondial, Bucureşti, Editura Orizonturi, Editura Lider, vol. 2, pp. 347-349.

[10] Soare, Vasile, Forţele speciale-comadouri aeropurtate în acţiune, Bucureşti, Editura Ziua, 2002, p.101.

[11] ***Histoire des opérations aéroportèes, Bruxelles, Elsevier Sequoi, 1979, ediţie franceză, tradusă şi adaptată după Airborne Operations, London, Salamander Books Ltd., 1978, p. 77.

[12] ***Histoire des opérations aéroportèes, Bruxelles, Elsevier Sequoi, 1979, ediţie franceză, tradusă şi adaptată după Airborne Operations, London, Salamander Books Ltd., 1978, p. 78.

[13] Hedny, Philippe, Malcros, Christian (coord.), Histoire mondiale des parachutistes, Société de Production Littéraire, Paris, 1974, p.71. 